\title{
Studies on adsorption of diphtheria toxoid on aluminium phosphate gel
}

\author{
N. Sivananda ${ }^{1}$ and B. Sundaran \\ ${ }^{1}$ Pasteur Institute of India, Coonoor, Nilgiris-643 103 Tamilnadu, India. \\ nanjansivananda@yahoo.co.in ${ }^{1}$
}

\begin{abstract}
Aluminium compounds are widely used as an adjuvant in Diphtheria, Tetanus, and Pertussis (DPT) group of vaccines. Diphtheria and tetanus toxoids are adsorbed on aluminium phosphate gel and used in the immunization. Generally a plain vaccine is less immunogenic. After adsorption it will have a repositary action. The present study envisages the adsorption rate of diphtheria toxoid on aluminium phosphate gel at different $\mathrm{pH}(5.0,6.0,6.5,7.0$ and 7.5). The main conclusion drawn from the experiments is that the low $\mathrm{pH}$ favours high adsorption rate.
\end{abstract}

Keywords: Diphtheria toxoid; aluminium phosphate gel, adsorption, vaccine.

\section{Introduction}

Diphtheria toxoid is prepared from the toxin produced during the growth of a suitable strain of Corynebacterium diphtheriae in an optimised medium. The toxin obtained is detoxified by the addition of formaldehyde and then concentrated by ultrafilteration and purified by ammonium sulphate fractionation (Rao et al., 1991). Adjuvants help antigen to elicit an early high and long-lasting immune response with less antigen, thus saving on vaccine production costs (Gupta \& Siber, 1995). Adjuvants have been applied to potentiate the immune responses to antigens in vaccinations for many years. Aluminium salts, especially the hydroxide or phosphate are the adjuvants used widely with routine human vaccines (Goto et al., 1993).

The major advantage of using aluminium adjuvants is their record of safety after primary immunization. The mechanism of adjuvanticity includes formation of a depot at the injection site, allowing slow release of antigen; stimulation of immunoreactive cells (Edelman, 1997). The Aluminium adjuvants have proved their efficiency in a large number of applications and they are fairly inexpensive (Lindblad, 2004a). The present study is an attempt to investigate the adsorption rate of Diphtheria toxoid on aluminium phosphate gel at different $\mathrm{pH}$.

\section{Methods}

Vaccine samples (Batch No: A, B \& C) were used for the study. The $\mathrm{pH}$ of the vaccine samples were adjusted to $5,6,6.5,7$ and 7.5 by using $1 \%$ hydrochloric acid or saturated sodium carbonate solution. Each set was incubated at $22 \pm 1^{\circ} \mathrm{C}$ for 3 days and then shifted to $+4^{\circ} \mathrm{C}$ with intermittent shaking. The percentage of adsorption was calculated after incubating the samples for 20 and 30 days.

\section{Estimation of Limes Flocculation or Limit of Flocculation} (Lf) $/ \mathrm{ml}$

The toxoid was distributed into 5 flocculation tubes in $1 \mathrm{ml}$ amounts. Graded doses of standard antitoxin (100 $\mathrm{Lf} / \mathrm{ml}$ ) was added so as to cover the expected range. The contents were mixed well and kept in a water bath maintained at $50^{\circ} \mathrm{C}$. The tubes which contain the optimum concentration of toxoid and antitoxin flocculate first and the corresponding unitage of the antitoxin was taken as the Lf value of the toxoid (Rao et al., 1991).

To each sample drawn added $0.5 \mathrm{~g}$ sodium citrate/10 $\mathrm{ml}$ and centrifuged at $3000 \mathrm{rpm}$ for 20 minutes. The supernatant was taken for the Lf titration to find out total Lf units. Another set of sample was taken in a centrifuge tube without the addition of sodium citrate, subjected to centrifugation at $3000 \mathrm{rpm}$ for 20 minutes. The supernatant was used to estimate the unadsorbed Lf units. From the difference between these two flocculation units the rate of adsorption was calculated.

\section{Results and discussion}

Aluminium compounds are widely used as an adjuvant in DPT group of vaccines. All the mixtures after formulation were held at $2-8^{\circ} \mathrm{C}$ for maturation. Rate of adsorption was estimated at the completion of 20 days and 30 days. The results are shown in Table 1 and 2 .

From the results it is clear that the samples held at $\mathrm{pH} 5$ showed the maximum adsorption by 20 days. A Significant adsorption of $90 \%$ obtained on further maturation period. The physicochemical mechanisms behind the antigen adsorption itself are complex and
Sivananda \& Sundaran Indian J.Sci.Technol. 
depend on the nature of the individual antigen. For many

protein antigens adsorption is accomplished in the $\mathrm{pH}$

Table 2. Adsorption rate at various $\mathrm{pH}$ after 30 days

\begin{tabular}{|l|c|c|c|c|}
\hline $\mathrm{pH}$ & $\begin{array}{c}\text { \% of } \\
\text { adsorption in } \\
\text { batch No. A }\end{array}$ & $\begin{array}{c}\text { \% of } \\
\text { adsorption in } \\
\text { batch No. B }\end{array}$ & $\begin{array}{c}\text { \% of } \\
\text { adsorption in } \\
\text { batch No. C }\end{array}$ & $\begin{array}{c}\text { Average \% } \\
\text { of } \\
\text { adsorption }\end{array}$ \\
\hline 5 & 90.90 & 90.90 & 90.90 & 90.90 \\
6 & 72.72 & 54.00 & 63.63 & 63.45 \\
6.5 & 63.63 & 54.00 & 63.63 & 60.42 \\
7 & 54.54 & 36.36 & 54.54 & 48.48 \\
7.5 & 36.36 & 27.27 & 36.36 & 33.33 \\
\hline
\end{tabular}

Values are expressed as mean of 6 samples in batch No. $A, B \& C$.

interval between the isoelectric point of the protein antigen and the point of zero charge of the aluminium adjuvant (Lindblad, 2004b). The tables show that, as the $\mathrm{pH}$ increases the rate of adsorption decreases. According to earlier studies (Gupta, 1998), adsorption of antigen onto aluminium compounds depends heavily on electrostatic forces between adjuvant and antigen. This may possibly due to the $\mathrm{pH}$ of the reaction mixture. When we approach iso-electric point of a protein molecule

Table 1. Adsorption rate at various $\mathrm{pH}$ after 20 days

\begin{tabular}{|l|c|c|c|c|}
\hline $\mathrm{pH}$ & $\begin{array}{c}\text { \% of } \\
\text { adsorption in } \\
\text { batch No. A }\end{array}$ & $\begin{array}{c}\text { \% of } \\
\text { adsorption in } \\
\text { batch No. B }\end{array}$ & $\begin{array}{c}\text { \% of } \\
\text { adsorption in } \\
\text { batch No. C }\end{array}$ & $\begin{array}{c}\text { Average } \% \\
\text { of } \\
\text { adsorption }\end{array}$ \\
\hline 5 & 72.72 & 72.72 & 81.81 & 75.75 \\
6 & 63.63 & 54.00 & 63.63 & 60.42 \\
6.5 & 54.54 & 45.45 & 45.45 & 48.48 \\
7 & 45.45 & 27.27 & 36.36 & 36.36 \\
7.5 & 27.27 & 27.27 & 27.27 & 27.27 \\
\hline
\end{tabular}

Values are expressed as mean of 6 samples in batch No. $A, B \& C$.

(Diphtheria toxoid, 4.1), the charge of the molecule is more as it is amphoteric in nature.

\section{Acknowledgement}

We record our sincere thanks to Dr. B. Sekar, Director, Pasteur Institute of India (PII), Coonoor, Nilgiris, Tamilnadu, Dr. K.R. Mani, Director, Central Research Institute (CRI), Himachal Pradesh, Dr. K.N. Venkataramana, Asst. Director, PII, for their encouragement. We are deeply indebted to Dr. Y.U.B. Rao, former Deputy Director, PII, for his valuable guidance.

\section{References}

1. Edelman R (1997) Adjuvants for the future 14. In: New generation vaccines. $2^{\text {nd }}$ Edn., Levine MM, Woodrow Gc, Kaper JB \& Cobon GS (Eds.). Marcel Dekker Inc, USA.

2. Goto $\mathrm{N}$, Kato $\mathrm{H}$, Maeyama $J$, Eto $\mathrm{K}$ and Yoshihara S (1993) Studies on the toxicities of aluminium hydroxide and calcium phosphate as immunological adjuvants for vaccines. Vaccine. 11(9), 914-918.

3. Gupta RK and Siber GR (1995) Adjuvants for human vaccines-current status, problems and future prospects. Vaccine. 13(14), 1263-1276.

4. Gupta RK (1998) Aluminium compounds as vaccine adjuvants. Adv. Drug Delivery Rev. 32(3), 155-172.

5. Lindblad B (2004a) Aluminium adjuvants-in retrospect and prospect. Vaccine. 22, 3658-3668.

6. Lindblad B (2004b) Aluminium compounds for use in vaccines. $/ \mathrm{mm}$. Cell Biol. 82, 497-505.

7. Rao YUB, Ramadevi Venkateshwaran, Rohini Gideon and Vasanth Pandit (1991) Manual for the production and standardization of DiphtheriaTetanus-Pertusis Vaccine, pp: 12-19, Published by Pasteur Institute of India, Coonoor, Tamilnadu, India. 